Dans un cas comme dans l'autre, des grelots sont utilisés pour provoquer l'état d'hystérie désiré. Le praticien a droit à une rétribution pour sa consultation, mais celle-ci ne lui est versée que lorsque des résultats satisfaisants se sont produits. Il paraît évident que les activités des magiciens et le culte des ancêtres satisfont un besoin dans la vie spirituelle des Sukuma, en leur donnant une explication de leurs maux et de leurs malheurs. Par l'exercice de ses pouvoirs, le magicien maintient son tang dans la vie du village.

\title{
RESULT OF THE MARGARET WRONG PRIZE COMPETITION IN 1954
}

The Prize of $£_{20}$ for an original manuscript in English, French, Portuguese, or Afrikaans has been awarded to Issa Keita of Bamako, Soudan Français, A.O.F., for an essay entitled:

$$
\text { ' L'Esprit du Conteur noir' }
$$

The judges commended: F. James Oto, of Yaoundé, Cameroun Français, for verses entitled 'Les Heures souhaitées' and Bernard M. Onyango, of Tororo, Uganda, for an essay entitled 'Impressions on the lot of an educated African in East Africa with special reference to Uganda'. 